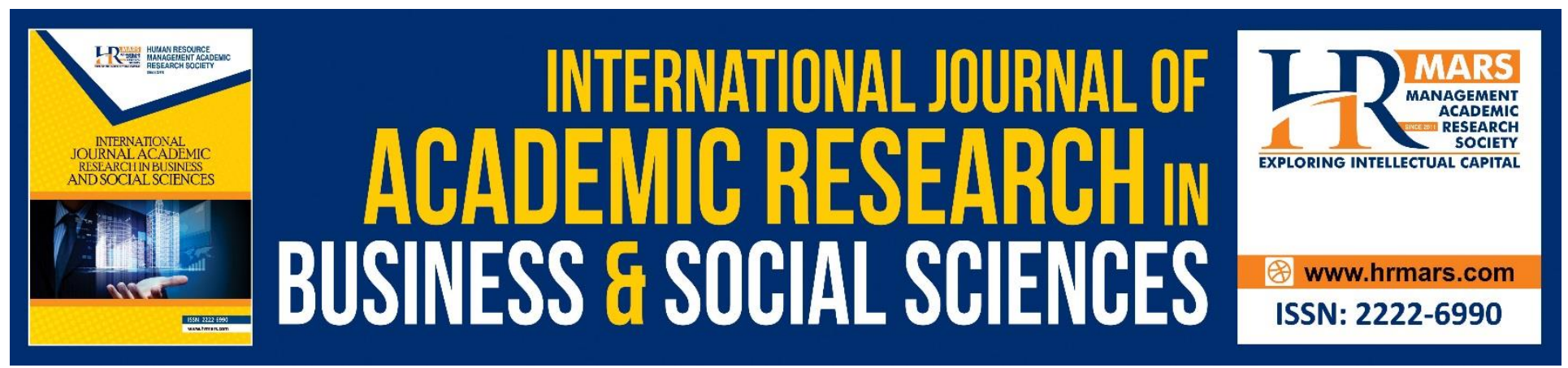

\title{
Criteria Classification of Class in The Suburbs Case Study: Northeastern Region of Thailand
}

\author{
Prapaporn Supunya, Dusadee Ayuwat
}

To Link this Article: http://dx.doi.org/10.6007/IJARBSS/v10-i14/7682

DOI:10.6007/IJARBSS/v10-i14/7682

Received: 07 April 2020, Revised: 13 May 2020, Accepted: 23 June 2020

Published Online: 25 July 2020

In-Text Citation: (Supunya \& Ayuwat, 2020)

To Cite this Article: Supunya, P., \& Ayuwat, D. (2020). Criteria Classification of Class in The Suburbs Case Study: Northeastern Region of Thailand. International Journal of Academic Research in Business and Social Sciences, 10(14), 123-133.

Copyright: (C) 2020 The Author(s)

Published by Human Resource Management Academic Research Society (www.hrmars.com)

This article is published under the Creative Commons Attribution (CC BY 4.0) license. Anyone may reproduce, distribute, translate and create derivative works of this article (for both commercial and non-commercial purposes), subject to full attribution to the original publication and authors. The full terms of this license may be seen at: $\underline{\text { http://creativecommons.org/licences/by/4.0/legalcode }}$

Special Issue: WSTI2018 - Issues and Trends on Education, Science and Technology, 2020, Pg. 123 - 133 http://hrmars.com/index.php/pages/detail/IJARBSS

Full Terms \& Conditions of access and use can be found at http://hrmars.com/index.php/pages/detail/publication-ethics 


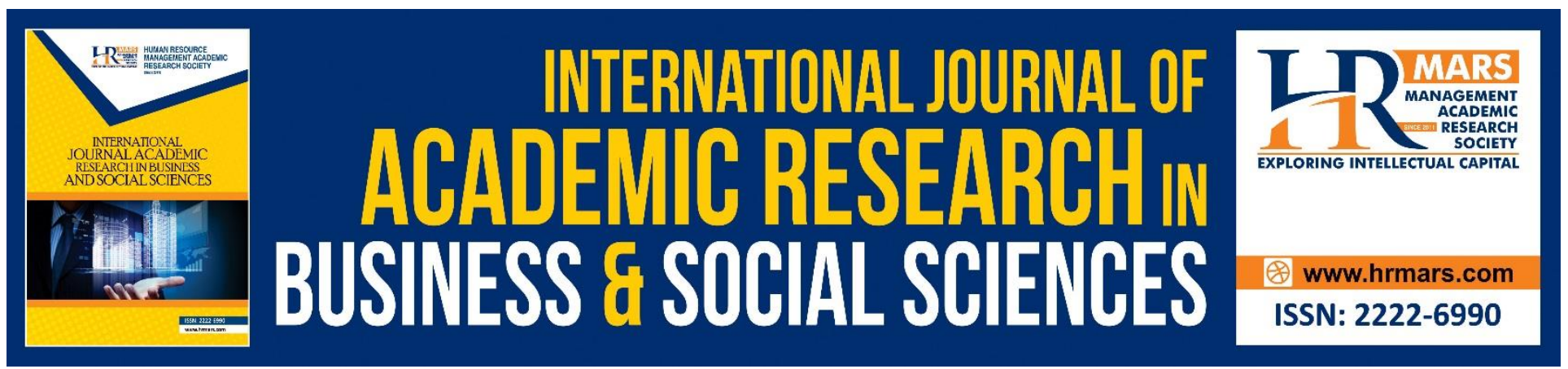

\title{
Criteria Classification of Class in The Suburbs Case Study: Northeastern Region of Thailand
}

\author{
Prapaporn Supunya, Dr. Dusadee Ayuwat \\ Department of Social Sciences, Division of Sociology, and Anthropology Labour and International \\ Migration Service Center, Faculty of Humanities and Social Sciences, Khon Kaen University, Khon \\ Kaen, Thailand \\ Email: dusayu@kku.ac.th
}

\begin{abstract}
This paper aims to identify new indicators of class at household level. Qualitative research methodology was implemented in the research design, and the research was conducted in a suburban area of a major northeastern city in Thailand. The research results found and identified four types of suburban households, which were 1) rich households, 2) middle class households, 3) lower middle class households, and 4) poor households. The research revealed seven indicators of class, that were 1) land, 2) occupation, 3) income, 4) assets, 5) convenient facilities, 6) education accessibility, and 7) medical accessibility. It was noticed that the suburban community focused on indicators of class which represented a mixed lifestyle between urban and rural lifestyles.
\end{abstract}

Keywords: Indicators of Class, Class, Suburban Community, Suburban Household.

\section{Introduction}

In the 20th century, urbanization has been introduced to the world, especially in many developing countries where the urbanization trend has invaded every single area of the country (Zhang, 2016). The United Nations estimates that the world population will increase by up to 2.4 billion people, or 66.0 percent of the current world population, in the next 35 years (in 2050) (United Nations, 2015). In Thailand, the government has implemented its National Economic and Social Development Plan as a guideline for the country's development. The plan has been conducted since its first issue $\left(1961\right.$ - 1966) until the $12^{\text {th }}$ issue $(2017-2021)$. The current plan has made a priority of economic growth, transportation, and development of infrastructure in order to support industry and the services sector. These developments have boosted the urbanization rate in Thailand, which has increased from 20 percent in 1960 to 55 percent in 2017 (World Urbanization Prospect, 2015). This has become a major condition that contributes to the country becoming an industry based country, in line with a modern, capitalist economy. Development in the urban areas has resulted in their expansion into the suburban areas. Rural populations have moved to work and live in urban areas increasingly (Sawangdee et al, 2007; Leoprapai, 1998) in order to seek better life opportunities. 
Khon Kaen was designated as the main city of the Northeast region of Thailand in the 4th National Economic and Social Development Plan (1977-1981), so the province has received infrastructure development (Community Development Office, 2560) for the province to become the center of the regional economy. Urban areas, that were once only around the CBD, have expanded to the suburban areas, and this has caused changes in lives of the rural people. The lifestyles of the rural people have been changing because of the facilities that have been developed in their communities, following the modernity trend. The people have more chance to access information and consume modern facilities, based on mainstream capitalism (Bourdieu, 1984). The changes in the lifestyles of the suburban people has led to a questioning of the indicators of class, which need to be reviewed in order to identify the new indicators of class in a society that increasingly relies on the capitalist trend, in the lifestyles of suburban people.

\section{Research Objectives}

To explore the indicators of class at household level among the suburban households in Khon Kaen city, Thailand.

\section{Literature Review}

The study of class indicators in suburban areas has adopted the concept of social class as the study's guideline. Social class has developed based on the study of class which is caused by social differentiation and has resulted in social inequality in society. From a sociological point of view, social class is a process of determining people of different status. The determining of class produces different individual values, dignity, and privileges, and it has determined an individual's position in society, such as being high society people or low society people. This is based on the values of the individual in society (Marger, 2005; Chantavanich, 2008). Therefore, social stratification is the process of determining that members of society exist in different positions.

Social stratification has been determined by many different individual indicators such as skin color, language, family background, education, occupation, economic status, social power, honor, reputation, prestige, etc. These different indicators are valued and are accepted by groups of people in society. Emile Durkheim (1897) explained this phenomenon as the social facts (Durkheim, 1897). In addition, some societies have a high determination of individual indicators so that there is an inequality in the societies (Tumin, 1967). Warner, an American sociologist, studied social class by using a new approach in his analysis. Warner extended the concept of the new social class by considering superior and inferior members in society. Indicators used in the analysis consisted of income, security, education, occupation, and housing (Warner, 1949). Warner identified six classes of people in society as 1) the upper-upper class, 2) the lower-upper class, 3) the upper middle class, 4) the lower middle class, 5) the upper-lower class, and 6) the lower-lower class. (Warner, 1949). This study implements the social stratification concept to determine the indicators of class, of the suburban people, within a modern social context. The output of this study will introduce new indicators.

\section{Research Methodology}

This paper employed qualitative research methodology, specifically the phenomenological approach, in the research design (Phothisita, 2004) in order to determine household-level indicators of class in a suburban community in Khon Kaen province. The units of analysis were the individual, 
household, and community. Key informant groups consisted of 1) community leaders and government officers (government officers included education-related officers, community development officers, policy and plan analysts, human resources officers, agronomists, teachers, healthcare officers, etc.), and community leaders including village headman, assistant village headman, and senior villagers, a total of 15 persons, in order to access the information concerning the dynamic of community settlement and the socio-economic background of the community. (2) suburban people aged between 18-59 years old, a total of 12 persons. These suburban people were those who worked in the city and lived in residences in the suburban areas. In-depth interview, participatory observation, and non-participatory observation were used as research tools, while group interview was used with 15 persons, who had various socio-economic backgrounds, to find out the indicators of class at community level. The data collection period was from March - October 2018 , and content analysis was used to analyze the indicators of class in the context of the Khon Kaen suburban community.

\section{Results}

The results consist of 2 parts: 1) contexts of the suburban community and 2) class and the indicators of class in the suburban household. Details of each part are as follows.

\section{Context of the suburban community}

The suburban community in this study was "Baan Dong Dok Mai" (fictitious name) with a population of 1,559. The community was located $18 \mathrm{~km}$ away from the Khon Kaen Municipality. The community was located close to a big pond, and was suitable for conducting agricultural activity such as rice farming, gardening, or raising livestock. Most agricultural activities were conducted for household consumption. Some household members worked as farm employees in the community. They undertook harvesting tasks. Some households had members working in the service sector of the urban area of Khon Kaen city such as laundry, housekeeping, etc., while some household members worked in manufacturing. In addition, some households had members who served in government positions such as teachers, nurses, and public health officials. The diversification of the occupations undertaken demonstrated a community value that focused on education, so there were many community members who had received education to a high level and were therefore able to obtain government jobs. It was noted that some households had developed their own businesses, such as grocery store, construction tool shop, mobile top up service, and agricultural tool shop. The diversity of the above occupations provided varying socio-economic status among the suburban households. The suburban households had adjusted their lifestyle to working more in nonagricultural activities, but their relationships in the community were still based on the kinship system which relied on the rural way and adhered to their Buddhist and traditional practices. In addition, it was found that the suburban households sustained their livings through agricultural activities alongside their other activities in the urban areas of Khon Kaen city.

\section{Class and indicators of class of the suburban household}

Key informants classified the households in the suburban community into 4 groups 1) rich household, 2) middle class household, 3) lower middle class household, and 4) poor household. They defined the rich household as "they can do anything without fault". It meant the rich households could do every activity such shopping, eating, dressing, or travelling because they had the money or 
other financial resources. This group represented roughly 20 percent of total households in the community. The definition of the middle class household group was "not poor if working hard". Households of this group were diligent in their work until they were able to improve their household's socio-economic status. If they needed something, they would apply great concentration until they achieved it. This group represented roughly 30 percent of the total households in the community. The definition of the lower middle class household was "month by month" in which they had to work hard. However, their household income seemed to be insufficient for their household expenses. This group represented roughly 40 percent of the total households in the community. Finally, the definition of a poor household was "the day by day life"; that is the households did not have enough income to sustain themselves. Some days they could not find something to eat, and sometimes they had no income. This group represented roughly 10 percent of the total households in the community, or about 30 households.

It can be seen that the classification of households in the suburban community, by the locals, was conducted based on a new approach to social stratification which focused on superior and inferior members in the community. This type of classification was similar to Warner's study (Ritzer, 1992; Turner, 2003) that mentioned a new social stratification. Moreover, this research also reflected that the middle class household was the most influential household group in the social phenomena within the modern society that focuses on the power of money and the convenience of things. The definition given by the locals reflected a lifestyle that responded to their own needs so that it made them adjust themselves greatly. These findings supported Bourdieu (1984) who suggested that the middle class was the most active group within modern social change.

The classification of household group was conducted through the determination of both economic indicators and social indicators. The indicators implemented are described as follows.

\subsection{Economic indicators}

When social class was brought in to consideration, economic indicators seemed to be the perfect indicator representing class in society (World Bank, 2018 and Barber, 1957). The common economic indicators used in the past consisted of land owning, assets, and income (Chantavanich, 2008). In this study, the economic indicators used to represent household status in the suburban community were all follows.

2.1.1. Land ownership and land use; based on the villager's perception, land was the most important economic indicator in order to identify a household's status. The rich household group owned a lot of land, which they owned due to inheritance or through purchase. They owned 20 Rai, or sometimes more. They used the land for many purposes such as housing, farming, business, or allowed other households to rent it. This was another way of making household income for the rich group. While the middle class household group owned land between 5 to 20 Rai, they used it for housing, conducting mixed-farming, or allowed other households to rent it for agricultural activity. The lower middle class household group; although they had their own land for housing, did not have land for agricultural activity. They had to rent land from other villagers. The poor household group; they had neither land for housing nor farming. They had to rent land from other villagers. The

situation facing the poor households was described by a middle-aged woman in an interview "My parents did not have many assets because they had many kids. There was not enough for everyone. When my parents died, we had to sell our assets in order to clear debts. That is why we do not have 
our own land or house. I had to rent land for housing. I pay the rent sometimes, if I have it. Some months the land owner allows me to live for free because they take pity on me.... "

In the past, land ownership was an indication of who is a rich man in the village (Warner, 1949), but today the villagers have turned their focus to land use. Those who use their land for multiple purposes, such as for housing, business, or mixed farming would be classified as the rich men of the village.

2.1.2. Occupation and income; the rich household group would have stability of occupation. They would receive incomes from many sources such as from their routine occupation or farming, as well as from land rental. Therefore, they had plenty of cash. In addition, some households conducted large-scale businesses in the community, such as construction materials shop, gas station, etc. The middle class household group; they had a stable occupation and income from regular jobs. They had an income of higher than 15,000 Thai Baht, which was the standard monthly wage paid in Khon Kaen province. The lower middle class household group; the household members generally worked in an industrial factory or were employed in farming. They received both monthly wages and a daily wage. The poor household group; they did not have regular jobs. Most households worked in agricultural activity in the community and in nearby communities. They received a daily wage of 300 Thai Baht, which was the legal minimum. They lacked opportunities to seek jobs as, in a quotation from a senior woman, "I have money only on the day I have a job. If no one hires me, I have to be patient and look forward to seeking a job, day by day ... "

It is noticed that, in the past, the indicator of their occupation was used to measure the social status of people in society (Weeden and Grusky, 2012). In Thailand, occupations were a mechanism tool used to stratify people. For instance, medical professionals were recognized as high class people (Chantavanich, 1988). However, being a trader was an occupation that generated high income to raise social status. This brought about a shift in the view of occupation among the villagers who viewed being a trader as an honored occupation. Regarding income, those who have a high income would be considered as the high-class people in the community (Sernau, 2014). However, presently incomes are able to be generated from various sources such as routine job, farming activity, investing in a mutual fund, etc. Therefore, this is another indicator that determines the status of people in the village.

2.1.3. Assets; the rich household group owned a lot of inherited property. They had land in the community and land in urban areas, which they bought for their children (who study in the city). They also had rooms for rent, and bought condominiums for speculation purposes. They had all types of vehicles and facilities. The middle class household group; owned inherited property such as land and houses. They had properties in the same way as the rich household group, but they did not have as much as the rich household group. They also had all types of vehicles and facilities. The lower middle class household group; had less properties than the first two household groups. Some households sold inherited property to clear debts, while some had no inherited property. It was noted that the poor household group did not have any properties because they were too poor to have accumulated valuable property, and they could not access an income source.

The indicator of property was essential to stratify the class of people in the past. The most common indicators were considered to be through the ownership of production inputs, such land, number of cattle, etc. (Weedom and Grusky, 2012). However, the criteria of class indicators regarding 
assets has shifted from production inputs to the ownership of assets that are household facilities such as land, houses, dormitories, vehicles, and others. This is a new indicator that was found in the suburban community.

2.1.4. Savings (Baht per year); the rich household group had savings of more than $1,000,000$ million Baht, while the middle class household group had more than 100,000 Baht in savings. The lower middle household group had savings of about 1,200 Baht, which was generated from saving in the local Credit Union at 100 baht per month, or 30 Baht per month in some households. The level of savings per month depended on household efficiency. There were officers from the financial company who came to the community to collect the savings money every month. However, it was reported that there were no savings for the poor household group.

At present, the amount of savings is used as an indicator to represent the class of people in the urban community. It is concluded that community members pay attention to the value of cash. Those who have large savings would be considered as the rich men in the suburban community.

2.1.5. Convenient Facilities (home facilities); the rich household group generally had many home facilities. They had between 1-11 pieces of home equipment including fan, washing machine, iron, refrigerator, television, air-conditioner, hot shower, water filter, microwave, exercise machine, and security camera (CCTV). The middle class household group had less home facilities than the rich household group. They had between 1-9 pieces of home equipment including fan, washing machine, iron, refrigerator, television, air-conditioner, hot shower, microwave, and exercise machine. The lower middle household group had 1-6 pieces of home equipment including television, fans, refrigerators, washing machines, irons, and thermos flask. The poor household group had 1 - 2 pieces of home equipment including television and fan, which were purchased with government support. They bought from the grocery store within the community, and they only bought items their households needed.

Equipment and Machinery; the rich household group had large tractors, trucks, rice harvesting machine, and all types of agricultural equipment. The middle class household group had agricultural equipment the same as the rich household group, but they owned fewer items than the rich households. In the lower middle class household group, some households, had a big tractor and agricultural equipment, but the poor household group did not have any agricultural equipment or related tools to conduct their occupation.

Communication Facilities such as telephones, computers, notebooks, and iPads. The rich household group had all these types of communication facilities. Everyone in the household had their own telephone. Those who had a business would have more than one telephone, and the phones were mostly supported by the Android operating system, with functions that supported their business. The middle class household group had communication facilities the same as the rich household group, but they owned fewer items than the rich households. Some households had 1-5 telephones, and they used expensive phones from luxurious-brands such as Samsung and iPhone. The lower middle class household group had 1-3 telephones. Their cost would not exceed 8,000 Baht, and would be paid for using "EON" credit card. Some households had computers. The poor household group had only 1 telephone or, in some cases, none. They bought their phone from the telephone 
operators at a cheap price. They bought their phone for only 100-200 Baht. The functions on the telephone were limited only to making calls.

Vehicle Equipment (number and type of vehicles); the rich household group had 3-4 cars, 2 or more motorcycles, while the middle class household group had 1-2 cars and 1-2 motorcycles. The lower middle class household group had only one motorcycle, and the poor households had no motorcycle. They only had a bicycle.

Indicators on facilities were new indicators found in the suburban community. It demonstrated a new, modern lifestyle that focused on convenience. This was different from the past when there were not so many convenience items available to individuals and households. This is another indicator that demonstrates the differences among people in society (Bourdieu, 1979) because of the number of facilities able to indicate patterns of consumption in modern society.

In conclusion, the economic indicators that were explored in the suburban area consisted of 1) land; which was considered through purposes of land usage, 2) occupation and income; the community did not admire those who worked in the government sector as in the past, but paid attention to business owners because of the large amount of income available to these households, greater than from a government job. 3) Assets; ownership of various types of asset was a new indicator added to the suburban community, and 4) savings and 5) facilities were also indicators for the suburban community. It is noted that the economic indicators are more diverse, in accordance with a modern society that focuses on the convenience of life. This finding supported Bourdieu's study (1979) which found that economic indicators were tied to the status of individuals in society, so it created the different lifestyles of the individuals.

\section{Social Indicator}

Another indicator presented in the suburban community is that of social indicator. The country's urban development introduced a number of development projects to both rural areas and suburban areas. The suburban communities have easier access to infrastructure and services provided by the government. Social indicators consisted of education accessibility and medical accessibility as follows.

2.2.1. Education accessibility; the rich household group focused on education because they wished to use the knowledge learnt from education to develop their business. Therefore, they provided a good education for their children. Parents preferred to send their children to study in the provincial school, in urban areas, and many children graduated with a Bachelor degree or higher. The middle class household group; most household members graduated with a Bachelor degree. Their children had the chance to study in urban areas, the same as the rich household group. The lower middle class household group; they mostly sent their children to schools near their community due to economic limitations. Their children had the chance to study up to secondary school level (grades 3-6), this education was provided by the government. For the poor household group, their members graduated from primary school (grades 4-6). It was noted that their poor economic status did not allow them to continue to higher education.

2.2.2. Medical accessibility; the rich household group was able to choose the medical services they preferred. They were able to use the services with government support such as social security, 
health Insurance rights, or they used services from private hospitals in the case that they needed rapid treatment. Based on an interview, the household members preferred using the private hospital as per this quotation "... if my household member got ill with serious symptoms, I would take them directly to a private hospital. I would not waste time in queues at the public hospital. We have health insurance. We can claim on the insurance at the private hospital ... "

The middle class household group use medical services in the same way as the rich household group. They preferred using the private hospital because they wanted a fast service. The lower middle class household group chose to use medical services provided by the government. When they needed medical healthcare, they went to the large public hospitals. There were 2 such hospitals in Khon Kaen city. They could claim medical expenses from the social security agency or from the company they worked for. In case of minor illness, they went to the Don Chang Promotion Healthcare Hospital, while the poor household group used the free public services at the local hospital in a nearby community. If they suffered a minor illness, they treated themselves by buying medicine at a drug store in order to avoid the expense of a trip to use the service at the public hospital in the city. However, it was noted that all households were able to access the public service for free. It was a fundamental welfare provided by the government.

When the development projects expanded to the suburban community, people in the community had the chance to receive a higher level of education, they were able to undertake occupations in the urban areas, and access medical services provided by the government, more easily. People nowadays access education easily and equally. The suburban households realize the importance of education as a tool to mobilize their social status (Richardson, 2012) and consequently access good occupations. Regarding medical accessibility, this is an indicator of infrastructure development by the government, because villagers can get good welfare from their work (Devaux, 2014).

The indicators used to stratify classes of people are different from in the past, which focused on the economic dimension. However, the development of an urban society has led to a change in lifestyle, so the community has agreed to apply other dimensions, such as social indicators, to the index of indicators of class.

\section{Conclusion and Recommendation}

The study of indicators of class, at household level, among the suburban households in the Northeast region of Thailand is an attempt to explore the index of social stratification among the suburban households. Economic indicators included land, occupation, income, assets, and living facilities while social indicators included education accessibility and medical accessibility. The community combines the traditional indicators, i.e. land and occupation, with the new indicators that are gathered from the changes to social conditions, i.e. income, asset, and living facilities. It is found that the indicators of class in the suburban community are based on an urban lifestyle of people who work in the city and a rural lifestyle that still relies on traditional practices and agricultural-based activity. Therefore, the outputs of this study present the current indicators of class that reflect the people's ways of life in a suburban community that gradually changes into an urban community. Therefore, the relevant agencies that are responsible for screening households to receive benefits and compensations from the government agencies should focus on new household-level indicators to consider the households participate properly, in order to reduce the gap in social class of the modern suburban society. 


\section{Acknowledgement}

This paper is a part of Ph.D. Dissertation entitled "Lifestyle of the suburban people in social stratification", funded by Research and Training Center for Enhancing Quality of Life of Working Age People, Khon Kaen University. Finally, sincere gratitude is extended to all key informants especially the community leaders and the suburban people who participated and provided useful information for this paper.

\section{References}

Barber, B. (1957). Social Stratification: A Comparative Analysis of Structure and Process. New York: Harcourt.

Bourdieu, P. (1979). La distinction. critique sociale du jugement. Paris: Edition Minuit.

Bourdieu, P. (1984). Distinction: A Social Critique of the Judgment of Taste. Cambridge, MA: Harvard University.

Chantawanich, S. (1988). Social Stratification: Honors of Occupations in Thai Society. Bangkok: Chulalongkorn University Press.

Chantawanich, S. (2008). Sociological Theory. Bangkok: Chulalongkorn University Press.

Devaux, M. (2014, February 25). Nutrition and inequalities in health; the role of prevention policy, OECD-Health Division. Athens.

Durkheim, E. (1897). Suicide: A Study in Sociology, Translated by John A. Spaulding and George Simpson, edited by George Simpson. Eighth Printing. New York: Free Press. (First English translation 1951).

Leoprapai, B. (1998). Social Sector Decentralization and Human Welfare in Thailand. Journal of Population and Social Studies, 6(1-2), 85-121.

Marger, M. N. (2005). Social inequality: pattern and processes ( $3^{\text {rd }}$ ed). New York: McGraw-Hill.

Photisita, C. (2009). Sciences and Arts of Qualitative Research. Bangkok: Amarin Printing and Publishing.

Richardson, R. (2012). Changing life chances; practical projects and endeavours in schools. Sterling: Trentham Books.

Ritzer, G. (1992). Contemporary Sociological Theory, (3rd ed.). New York: McGrawHill, Inc.

Sawangdee, Y. (2007). The Growth of the Junction City: A Case Study of Nang Rong District, Buriram Province, Population and Society 2007. (Worachai Thongthai and Sureeporn PunPeung. Editors). Nakorn Pathom: Institute of Population and Social Research, Mahidol University.

Sernau S. (2014). Social inequality in a global age, London: Sage.

The Khon Kaen Community Development Office. (2017). The 2017 Report of Quality of Life of Khon Kaen People. Khon Kaen : the Khon Kaen Community Development Office.

Tumin, M. M. (1967). Social stratification; the forms and function of inequality, Englewood Cliffs. New Jersey: Prentice-Hall.

Turner, J. H. (2003). The Structure of Sociological Theory ( $7^{\text {th }}$ ed.). Belmont California: Wardsworth.

United Nations. (2015). World Urbanization Prospects: The 2014 Revision. New York: Economic and Social Affairs.

Warner, W. L., \& Meeker, M., \& Eells, K. (1949). Social class in America: A Manual of procedure for the measurement of social status. Chicago: Science Research Associates.

Weeden, K. A., \& Grusky, D. B. (2012). The three worlds of inequality, American Journal of Sociology. 
INTERNATIONAL JOURNAL OF ACADEMIC RESEARCH IN BUSINESS AND SOCIAL SCIENCES

Vol. 10, No. 14, Special Issue: WSTI2018 - Issues and Trends on Education, Science and Technology, 2020, E-ISSN: 2222-6990 @ 2020 HRMARS

World Bank. (2018). GDP per capita. Available:org/indicator/NY.GDP.PCAP.CD. Retrieved from http://data.worldbank.

Zhang, X. Q. (2016). The trends, promises and challenges of urbanization in the world. Habitat International, 54(1), 241-252. 